\title{
USING POETRY AS A MEANS OF AESTHETIC EDUCATION OF STUDENTS AT CLASSES OF FOREIGN LANGUAGE IN PEDAGOGICAL HIGHER EDUCATIONAL ESTABLISHMENTS

\author{
ВИКОРИСТАННЯ ПОЕЗІЇ ЯК ЗАСІБ ЕСТЕТИЧНОГО ВИХОВАННЯ \\ СТУДЕНТІВ НА ЗАНЯТТЯХ 3 ІНОЗЕМНИХ МОВ
} У ПЕДАГОГІЧНИХ ЗАКЛАДАХ ВИЩОЇ ОСВІТИ
}

The article tells about the use of poetry in the classroom of foreign language (English) as a means of aesthetic education of students of pedagogical institutions. In this article, aesthetic education is treated as a purposeful, systematic process of human development, which includes familiarization with the culture of the country of the studied language, characteristic of its norms and values; to develop aesthetic views, tastes, feelings and needs in creating beautiful.

It has been found that poetry can be used as a model of modern authentic colloquial and literary language to achieve the leading goals of learning and to develop the creative abilities of students. The effectiveness of the use of poetry samples largely depends on the properly organized sequence of work with them and the choice of exercises that stimulate students mental activity and promote the development of their motivation. Since the purpose of teaching a foreign language is not only the acquisition of knowledge, students' skills and abilities, but also their assimilation of information of local lore and cultural and aesthetic nature, knowledge of the values of another national culture is the question of cultural component. This component includes certain knowledge (language and cultural), as well as skills and abilities (language and nonlanguage behavior).

It has been established that acquaintance with poetry of the studied language contributes to the spiritual enrichment of students, the development of their ethical views and aesthetic taste. The study of English poetry stimulates the cognitive activity of students, develops their thinking. Involvement in the best examples of foreign poetry helps to overcome national cultural centrism and broadens the horizons of students. As a result of introduction of the presented material in educational process of students of pedagogical specialties, in particular future teachers of a foreign (English) language, the authors concluded productive use of specimens of English poetry to achieve leading training purposes namely, on the aesthetic education of future teachers.

Key words: aesthetic education of students, poetry, pedagogical higher educational establishments, "dialogue of cultures", development of creativity.

У статті розглядається використання поезії на заняттях іноземної (англійськоі) мови як засіб естетичного виховання студентів педагогічних закладів. Естетичне виховання досліджується авторами як чілеспрямований, систематичний процес людського розвитку, що містить ознайомлення з культурою країни досліджуваної мови, характерних для неї норм і системи цінностей; виховання естетичних поглядів, смаків, почуттів, потреб у створенні прекрасного.

З'ясовано, що поезію може бути викорис тано як зразок сучасної автентичної розмовно-літературної мови для досягнення провідних цілей навчання та для розвитку творчих здібностей студентів. Есектив ність використання зразків поезії значною мірою залежить від правильно організовано послідовності роботи з ними й вибору вправ, що стимулюють розумову діяльність студентів і сприяють розвитку в них мотиваціі. Оскільки метою навчання іноземної мови є не тільки придбання знань, формування в студентів навичок і вмінь, а й засвоєння ними відомостей країнознавчого й культурно естетичного характеру, пізнання цінностей іншої для них національної культури, то під час визначення змісту навчання безперечно постає питання про культурний компонент. Такий компонент містить певні знання (мовні й культурологічні), а також навички й уміння (мовної та немовної поведінки). Установлено, що знайомство з поетич ними творами країн мови, що вивчається, сприяє духовному збагаченню учнів, розви тку їх етичних поглядів та естетичного смаку. Вивчення англійської поезії стимулює пізнавальну активність студентів, розви ває їх мислення. Залучення до кращих зразків іноземної поезії сприяє подоланню національного культурочентризму й розширює кругозір учнів.

у результаті впровадження викладеного матеріалу в навчальний процес студентів педагогічних спеціальностей, зокрема майбутніх викладачів іноземної (англійської) мови, автори засвідчують продуктивність використання зразків англомовної поезі для досягнення провідних цілей навчання а саме естетичного виховання майбутніх педагогів.

Ключові слова: естетичне виховання сту дентів, поезія, педагогічні вищі навчальні заклади, «діалог культур», розвиток творчих здібностей.
Formulation of the problem in general. Aesthetic education of students of pedagogical higher educational establishments is carried out in close unity with all other types of upbringing. The most important conditions of their effectiveness are knowledge and true practical application of General pedagogical principles, the right choice of forms and methods of aesthetic education and upbringing.
Nowadays, because of the improvement of the quality of political, social, and economic transformations in society, the improvement of the framework of spiritual and moral life is determined by the potential of the human factor, knowledge, vitality, initiativity and creative activity of people. Of great importance in the development of creativity of a man is his ability to transform the surrounding reality. 
Analysis of recent research and publications. Many researchers and teachers of English highlight the aesthetic education as a crucial part of the hole educational process. Such researchers as I.D. Bech, N.G. Kalashnik, N.P. Kolesnikov, V.M. Maslennikov, N.V. Necheporenko, B.M. Nemean, L.V. Sukhodolskaya-Kuleshova studied the problem of aesthetic education, while L.L. Gabidullina, I.E. Syrtsova, T.A. Vdovina, N.P. Dolmatova devote their works to the problem of literary texts and works as a factor of cultural impact. But nevertheless, the power of poetry and its role in educational process, as well as its influence on aesthetic education hasn't been considered enough.

Selection of previously unsolved parts of the overall problem. The modern teachers are not only professional in their field of expertise, but also people with a high level of aesthetic culture. Today, it is, in our opinion, not always the case. Analysis of the theory and practice of aesthetic education in pedagogical higher educational establishment shows that the most important reason for the insufficient level of aesthetic education of students is the lack of preparedness of teachers to this important sphere of educational work. So, the English teacher is not always able to analyze works of art, particularly poetry, at lessons and extra-curricular activities, often does not possess the ability to create emotional and aesthetic atmosphere in the class, to provide an aesthetically-educational impact of their subject.

Actually, the solution to the problem of effective use of English and American poetry as a means of aesthetic education in the English classes was determined by the relevance of the article.

The main reason for this is the lack of aesthetic training of future teachers. It so happened that in the pedagogical practice of the past issues of the aesthetic training of the future teachers had not received adequate assessment and adequate reflection on the pages of scientific-methodical literature.

The purpose of the article is to clarify the role of aesthetic education in the development of students' creativity by means of poetry.

Presenting main material. In this article, aesthetic education is treated as a purposeful, systematic process of human development, which includes familiarization with the culture of the country of the studied language, characteristic of her norms and values; to develop an aesthetic views, tastes, feelings and needs in creating beautiful.

Without doubt, the role of aesthetic education in the development of the creativity of the individual is necessary and not accidentally, many thinkers of the past (Plato, J.H. Pestalozzi, Friedrich Schiller and others) emphasized the need to bring aesthetic principle in teaching of any academic subject [7, p. 32]. In our opinion appropriate and productive seems to be a solution to this problem in the process of learning a foreign language, as the aesthetic potential of this subject cannot be overemphasized. In the classroom a foreign language teacher has the opportunity to shape the artistic culture of students' personality to develop creative abilities, to influence the improvement of the level of aesthetic behavior oriented on "dialogue of cultures", and also to respect the point of view of the interlocutor and tolerant attitude to the partner.

The problem of the organization of teaching foreign languages at the pedagogical higher educational establishment is relevant and can be solved in different ways. A very interesting and productive is the use of samples of English poetry to achieve leading training purposes.

Familiarity with the poetic works of the country of the studied language contributes to the enrichment of students, development of their ethical beliefs, and aesthetic taste. The study of English poetry stimulates cognitive activity of students, develops their thinking skills, and introduces them to the culture of the people whose language they are studying. An introduction to the best samples of foreign-language poetry contributes to the expanding horizons of students [5, p. 20].

Working on the poetic compositions promotes active creative activity of students and stimulates motivation to learn a foreign language. Systematic work on the poems develops and promotes the enrichment of the spiritual world of the student, instills sensitivity to the poetic word, teaches them to see the beauty of nature. Poetry gives impulsion to the creative imagination and has great potential of emotional impact.

Great attention should be paid to the selection of poems, which are based on thematic, educational and didactic principles.

The analysis of the literature on this issue has shown that aesthetic education at foreign language classes is, first, in forming the skills to perceive aesthetic linguistic information; secondly, to develop the ability to see the beauty of the word; thirdly, in the process of developing skills for coherent speech on the basis of the best examples of literature, music, painting; fourthly, in raising aspirations to create its own broadcasting according to the laws of beauty [8, p. 176]. Research scientists (L.S. Vygotsky, I.P. Krupnik, A.M. Leontiev, S.L. Rubinstein) prove conclusively that thanks to the works of art activates the creative activity. As a result of the impact of artistic images harmonized the inner world of man, develops the ability to perceive and transform reality according to the laws of beauty.

One of the modern approaches in teaching foreign languages is the use of the art technology. Psychologists say that the inclusion in the educational process of artistic stimuli (poetry, music and painting) creates a positive emotional climate for teaching foreign language, causes positive emotions of students, and increases the efficiency of the achievement of different learning objectives. 
Using the integration of voice, music and drawing, the teacher carries out the activity approach. Deepening the integration of facial expressions, gestures, movements, increases motivation to learn the language that contributes to the emotional perception of the material.

Educational value of art is undeniable, it develops the intellect and soul, has an impact on the aesthetic education of the students' individual [3, p. 160].

Poetry can be used as a sample of authentic modern colloquial-literary speech to achieve leading training purposes and for the development of creative abilities of students. The effectiveness of the use of samples of poetry largely depends on well-organized sequence of work and exercise choices, which are stimulated by mental activity of learners and contribute to the development of their motivation [4, p. 80].

Since the goal of language learning is not only acquiring knowledge, developing students' skills and abilities, but also the assimilation of information, cross-cultural and cultural - aesthetic nature, the knowledge of the values of another national culture, in determining the content of teaching without doubt raises the question of the cultural component. This component includes some knowledge (linguistic and cultural), as well as skills and abilities (verbal and nonverbal behavior). Selecting the content of the national-cultural component of the variety of linguistic materials something that has pedagogical value and is able to promote not only learning a foreign language communication, but introduction to the culture of the country of that language is usually emitted.

Consequently, the study of culture in the learning process makes a significant contribution to the education of the younger generation. The subject "Foreign language" thus occupies a special place. It not only introduces the culture of the target language, but by comparing sets off the features of their national culture, introduces universal values.

Introduction to the materials of cultures contributes to the revival of cognitive motivation, the students are not only learning the program material, but also learn about unknown facts of culture, which undoubtedly gives them interest. Therefore, the learning process taking into account the interests of the students becomes particularly effective.

If we are talking about the use of poetry at a foreign language lessons it should be noted that such activity allows you to explore the poetry, the culture and customs of the country of studied language, which is always relevant.

Thus, what gives the work on the verse in the process of learning English?

1. Develops aesthetic taste of the pupils, their creativity. Positive attitude to poetry, to English in particular.

2. More strongly absorbed, and expanding vocabulary students. In verses meet the realities of the country of studied language, new words. It promotes the development of pupils' sense of language, knowledge of its stylistic features.

3. The poem helps one learn and reinforce grammatical structures.

4. When learning a poem improved listening skills, spoken skills, lay down rules of utterance stress, especially rhymes. In the formation of phonetic skills students need to pay attention to the reading of poetry is also to show the beauty of the English language, its rhythms and sounds.

5. In the process of working on the poem again and activate many of the program topics ("Ecology", "Friendship", "Nature", etc.).

The first thing to consider when you're selecting a poem for your class is the level of language. If you end up having to explain every single word then the poem may well lose its spark. On the other hand, students won't need to understand every word to get the general idea of most poems so don't be put off if you think the language level is slightly above what they would normally be able to handle. As with songs, if the students are supported throughout and are pretaught some of the vocabulary, or given some visual aids to help them, they will be able to tackle more challenging texts than they are used to.

The selection of poems should be considered in its educational and practical value, and compliance with the following requirements:

- the availability of a language (the content of the familiar vocabulary or a very small percentage of unknown vocabulary);

- allowable work (some of the poems are given in the reduction);

- controversy;

- corresponding the studied grammar material.

Poems can be picked up thematically. Modern, classic literature is replete with a variety of lyrical poems on the seasons and nature. You can provide students with the poems of different poets that relate to certain types of poetry, for example, love lyrics, humanism, patriotism. It is recommended to ask them to find similar images and ideas expressed in poetry English poetry of a certain period, to draw their attention to the world of the character and ways of expressing his feelings.

Besides, the poem can be used to illustrate grammatical phenomena while learning and revising of material. The poem can be used as a model when making similar sentences in which highly repeated actions are used. Some poems you can use when learning both grammatical and lexical material on specific topics in a particular group. At classes you can use poems or excerpts from them that has become aphorisms, which can be marked either as a goal or as a summing up of the class. Sometimes it is advisable to acquaint students with available translations of poems, to compare them with the original. 
Conclusion. The use of poems while learning a foreign language plays a huge role in teaching phonetic, lexical and grammatical aspects of a foreign language. The use of poetry contributes to the development of basic communication skills of reading, listening, speaking, and the latter most often appears in the form of a discussion of the poetic work content that can cause a real debate in group, since the problems raised in poetry are universal, have a vital character, do not always imply unequivocal solution. Thus, poetry contributes to learning the main types of speech activity and allows you to use non-standard, creative types of exercise, which is the achievement of the learning goal. In this way the use of various poems at the foreign language class gives impulse to the creative imagination of students has a huge emotional impact.

In addition, poetry enriches the spiritual world, and instills sensitivity to the poetic word, teaches us to see the beauty of the poem. Reading poems, recitation, translation, make learning a foreign language more meaningful, motivated, increases the interest in learning a foreign language.

\section{REFERENCES:}

1. Бех І.Д. Виховання особистості : у 2 кн. Київ : Либідь, 2003. Кн. 2 : Особистісноорієнтований підхід: когнітивно-практичні засади. $344 \mathrm{c}$.
2. Білодід І.К. Деякі аспекти взаємодії пізнавальної і естетичної функції мови. Мова. Людина. Суспільство. Київ, 1977. С. 92-102.

3. Вдовіна Т.А. Літературний текст як засіб міжкультурної комунікації. Мовна освіта: шлях до європейської інтеграції : матеріали міжнародного форуму. Київ, 2005. С. 160-161.

4. Долматова Н.П. Літературний текст як фрактор культурного та естетичного впливу. Педагогіка та психологія. Вісник АПН України. 2004. № 2 (42). C. 79-86.

5. Калашник Н.Г. Вплив технічних засобів навчання на розвиток естетичних смаків. Теоретичні питання освіти та виховання. 2000. Вип. 10. C. $171-172$.

6. Колесніков Н.П. Етика. Київ : Wincom Inter, 2004. $208 \mathrm{c}$.

7. Нечепоренко М.В. Формування естетичної культури студентів : дис. ... канд. пед. наук : 13.00 .04 ; ХНУ імені В.Н. Каразіна. Харків, 2005. 190 с.

8. Лихачев Б.Т. Теория эстетического воспитания школьников. Москва : Просвещение, 1985. 176 с.

9. Методологія та методи виховання студентів : навчальний посібник / А.А. Де-Реча, В.П. Літвак, А.С. Маліновський та ін. Житомир : Видавництво Волинь, 2004. 172 c.

10. Суходольська-Кулєшова Л.В. Формування естетичної культури майбутнього вчителя. Педагогіка. 2003. № 7. С. 83-87. 